\title{
低温 $\left(20^{\circ} \mathrm{C}\right)$ UASB 反応器と常温 DHS 反応器を組み合わせた システムによる模擬奨油製造廃水の高負荷連続処理
}

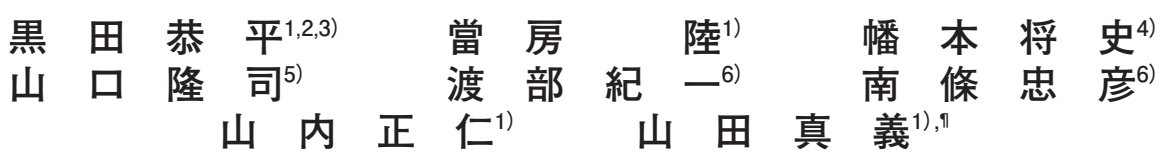

\author{
High Organic Loading Treatment of Synthetic Soy-sauce Production \\ Wastewater Using a Combined System Consisting of a Psychrophilic $\left(20^{\circ} \mathrm{C}\right)$ \\ UASB Reactor and a DHS Reactor at Ambient Temperature
}

\author{
Kyohei KURODA ${ }^{1,23)}$, Atsushi TOBO ${ }^{1)}$, Masashi HATAMOTO ${ }^{4)}$, \\ Takashi YAMAGUCHI ${ }^{5)}$, Norikazu WATANABE ${ }^{6)}$, Tadahiko NANJO ${ }^{6)}$, \\ Masahito YAMAUCHI ${ }^{1)}$ and Masayoshi YAMADA ${ }^{1), 1}$
}

\footnotetext{
1) Department of Urban Environmental Design and Engineering, National Institute of Technology, Kagoshima College, 1460-1 Shinko, Hayato-cho, Kirishima, Kagoshima 899-5193, Japan

2) Department of Creative Engineering, National Institute of Technology, Kitakyushu College, 5-20-1 Shii, Kokuraminamiku, Kitakyushu, Fukuoka 802-0985, Japan

3) Department of Energy and Environment Science, Nagaoka University of Technology, 1603-1 Kamitomioka, Nagaoka, Niigata 940-2188, Japan

4) Top Runner Incubation Center for Academia-Industry Fusion, Nagaoka University of Technology, 1603-1 Kamitomioka, Nagaoka, Niigata 940-2188, Japan

5) Department of Science of Technology Innovation, Nagaoka University of Technology, 1603-1 Kamitomioka, Nagaoka, Niigata 940-2188, Japan

6) Benears Co.,Ltd., 3-2-37 Mitsu, Matsuyama, Ehime 791-8061, Japan
}

\begin{abstract}
To establish an effective soy-sauce production wastewater treatment system, we designed a combined system consisting of a psychrophilic $\left(20^{\circ} \mathrm{C}\right)$ up-flow anaerobic sludge blanket (UASB) reactor and a down-flow hanging sponge (DHS) reactor under ambient temperature. The COD removal rate of $87 \pm 7 \%$ was achieved at a $26 \pm 3.6$ $\mathrm{kgCOD} \mathrm{m} \mathrm{d}^{-1}$ organic loading rate $\left(6,500 \pm 900 \mathrm{mgCOD} \mathrm{L}^{-1}\right.$ as influent synthetic soy-sauce based wastewater $)$ in the UASB reactor. 16S rRNA gene sequence analysis revealed that syntrophs belonging to class Deltaproteobacteria, phylum Firmicutes, and phylum Thermotogae, Bacteria belonging to phylum Synergistetes, and methanogens mainly degrade approximately $40 \%$ of the COD of soy-sauce-based synthetic wastewater in the UASB reactor. Syntrophic associations require low hydrogen partial pressure because of the difficulty of this reaction. Therefore, this study revealed that the UASB-DHS system can be applied to real soy-sauce production wastewater containing high organics and sodium concentrations because syntrophic associations were well developed.
\end{abstract}

Keywords: Synthetic soy-sauce production wastewater; Biological wastewater treatment; UASB-DHS system; Microbial community analysis based on 16S rRNA gene sequence

\section{1.はじめに}

奨油は日本を代表する調味料の一つであり，日本国内 の 1,330工場において年間 793,363 KL（2013 年現在）生 産されている1)。滰油の主な製造方法の約 8 割以上は伝 統的な製法である本醉造方式である。奨油製造では，副 産物として奨油粕と奨油油, また, 製造工程全体から廃
水が発生する（総合廃水）。奨油粕，奨油油については, 飼料化，肥料化や重油の代替燃料などとしてほぼ $100 \%$ 再利用がされている。しかし，滰油製造過程の珪藻土ろ 過から排出される廃水（以下，奨油製造廃水）は透明度 が低く，有機物濃度および塩濃度が高い，特有の臭いを 発する有機性廃水であり，再利用は殆ど行われていない。 一般的に総合廃水は，活性污泥法によって処理されてい

1 ）国立高等専門学校機構鹿児島工業高等専門学校都市環境デザイン工学科币899-5193＼cjkstart鹿児島県霧島市隼人町真孝 1460-1

2 ) 国立高等専門学校機構北九州工業高等専門学校生产デザイン工学科％802-0985 福岡県北九州市小倉南区志井 5-20-1

3 ）長岡技術科学大学大学院エネルギー・環境工学専攻％940-2188＼cjkstart新潟県長岡市上富岡町 1603-1

4 ）長岡技術科学大学産学融合トップランナー養成センター $=940-2188$ 新潟県長岡市上富岡町 1603-1

5 ）長岡技術科学大学大学院技術科学イノベーション専攻％940-2188＼cjkstart新潟県長岡市上富岡町 1603-1

6 ）株式会社ベネアス 下791-8061 愛媛県松山市三津 3-2-37

ๆ 連絡先 : m-yamada@kagoshima-ct.ac.jp 
るが2)，奨油製造廃水は高濃度有機性廃水（約 100,000 $\left.\mathrm{mgCOD} \mathrm{L} \mathrm{L}^{-1}\right)$ であることや, 活性污泥法で処理するには 曝気動力にかかるエネルギーの観点からも非効率である ため, 効率的な処理方法が求められている。

Up-flow anaerobic sludge blanket（UASB）法に代表 される嫌気性廃水処理法は様々な高濃度有機性廃水に適 用可能, 且つ, その処理過程でメタンガスをエネルギー として回収可能な優れた技術である ${ }^{3)}$ 。加えて, 嫌気性 廃水処理法は低温から高温までの幅広い温度条件下で, 高カチオン濃度含有廃水や生物毒性含有廃水にも適用さ れており，使用実績を確実に伸ばしている ${ }^{4 \sim 7)}$ 。しかしな がら, 嫌気性廃水処理のみでは排水処理基準を十分に満 たすことができない。そのため, 嫌気性処理により有機 物濃度が低減された廃水を曝気不要・省エネルギー型の 好気性処理が可能な Down-flow hanging sponge (DHS) 反応器8) を用いて後段処理することができれば, 上記問 題を克服しうる新規処理システムとして提案することが できると考えられる。

滰油製造工場では原料の大豆や小麦の洗浄に地下水を 利用することが多い。地下水は年間を通して $16 \sim 20{ }^{\circ} \mathrm{C}$ 前後 (平均約 $18{ }^{\circ} \mathrm{C}$ ) と水温の変化が少ないため ${ }^{9)}$, UASB 反応器の温度維持に地下水を利用することができれば, 反応器内の温度維持に使用する電力消費量を抑え, 且つ, 安定した温度管理下で奨油製造廃水のメタン発酵処理が 可能となる。一般的なメ夕ン発酵を用いた廃水の生物処 理プロセスでは, 中温 $\left(30-40{ }^{\circ} \mathrm{C}\right)$ 条件下での運転が使 用されているが, 産業廃水は低温で排出されることが多 いため, その加温にはエネルギーが必要である5)。近年, 低温（17-19 ${ }^{\circ} \mathrm{C}$ ) 条件下での Expanded granular sludge bed（EGSB）反応器を用いた飲料系工場排水の高負荷 $\left(15 \mathrm{kgCOD} \mathrm{m} \mathrm{m}^{-3} \mathrm{~d}^{-1}\right)$ メタン発酵処理にも成功するなど, 低温処理プロセスの実現可能性が示されている10)。そこ で本研究では, 奨油製造廃水を処理可能な低温 $\left(20^{\circ} \mathrm{C}\right)$ UASB 反応器と常温 DHS 反応器を組み合わせた高効率 廃水処理システムの開発を目的として, 模擬奨油製造廃 水の連続処理実験を行い, その処理性能の評価を行った。 加えて, 反応器内保持污泥の微生物叢を評価することで 本システム内の微生物学的知見の収集を試みた。

\section{2. 実験方法}

\section{1 UASB-DHS システムと供給廃水}

図 1 は本研究で用いたUASB-DHS システムの概要図 を示す。Gas Solids Separator（GSS）を含めたUASB 反 応器の液容積および DHS 反応器のスポンジ容積はそれ ぞれ 10 L, 20.8 L とした。UASB 反応器の槽内は $20{ }^{\circ} \mathrm{C}$ に制御し，DHS 反応器は無加温 $\left(10.4-31.1^{\circ} \mathrm{C}\right)$ とした。 UASB 反応器の植種污泥は中温条件 $\left(35{ }^{\circ} \mathrm{C}\right)$ で模擬奨油 製造廃水を COD 容積負荷 $30 \mathrm{kgCOD} \mathrm{m}^{-3} \mathrm{~d}^{-1}$, COD 除去 率 $82 \%$ で処理していた UASB 反応器のグラニュール污 泥を用い, DHS 反応器には下水処理場の返送污泥を用い た。本実験で対象とした滰油製造廃水とは，奨油製造の 最終工程で排出される廃水であり，市販の奨油とほぼ同 等の組成である。そこで実験では, 市販の奨油を水道水 で希釈することで供給 COD 濃度を調整し使用した。ま た, 供給廃水の COD の約 $40 \%$ は揮発性有機酸（VFA, COD あたり：酢酸 $48.3 \%$ ，プロピオン酸 $23.6 \%, n$-酪酸

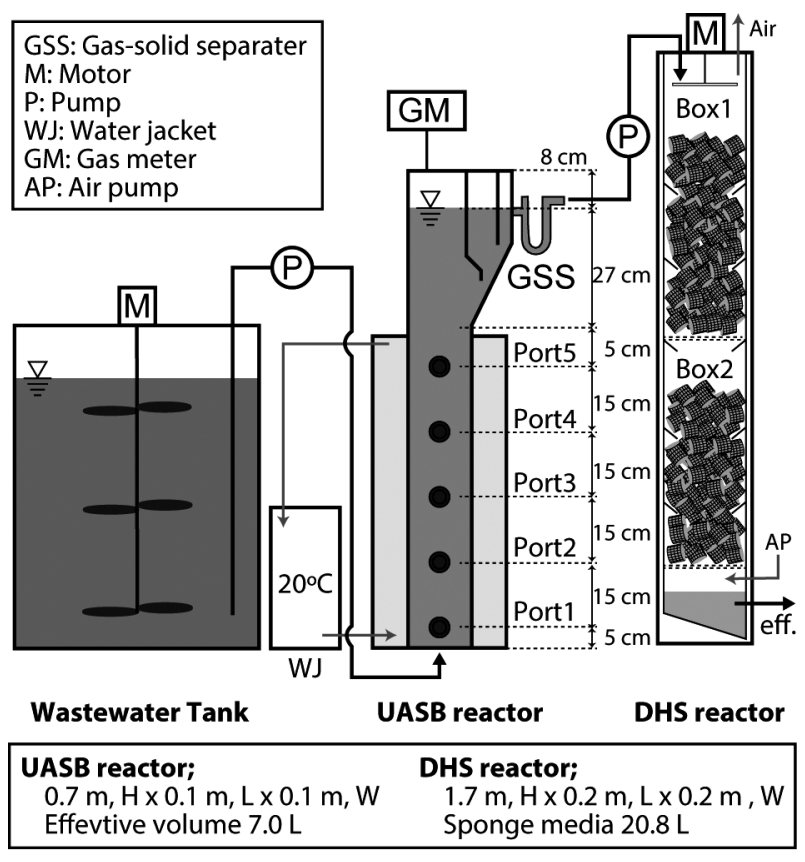

図 1 UASB-DHS システムの概要図

表 1 UASB 反応器の運転条件

\begin{tabular}{|c|c|c|c|c|c|}
\hline Phase & $\begin{array}{c}\text { 運転期間 } \\
\text { (day) }\end{array}$ & $\begin{array}{l}\text { UASB反応器 } \\
\text { のHRT (hr) }\end{array}$ & $\begin{array}{c}\text { 流入 COD濃度 } \\
\left(\mathrm{mgCODL}^{-1}\right)\end{array}$ & $\begin{array}{c}\text { COD容積負荷 } \\
\left(\mathrm{kgCCOD}^{-3} \mathrm{~d}^{-1}\right)\end{array}$ & $\begin{array}{c}\text { 塩濃度 } \\
\left(\mathrm{mgNa} \mathrm{L}^{-1}\right)\end{array}$ \\
\hline 1 & $1-85$ & 8 & $1,600 \pm 300^{*}$ & $4.7 \pm 0.9$ & 870 \\
\hline 2 & 86-131 & 6 & $1,300 \pm 400$ & $5.0 \pm 1.6$ & 700 \\
\hline 3 & $132-244$ & 6 & $2,200 \pm 600$ & $9.0 \pm 2.4$ & 1,190 \\
\hline 4 & 245-377 & 6 & $2,900 \pm 500$ & $12 \pm 2.2$ & 1,570 \\
\hline 5 & $378-455$ & 6 & $4,200 \pm 800$ & $17 \pm 3.2$ & 2,280 \\
\hline 6 & $456-656$ & 6 & $6,500 \pm 900$ & $26 \pm 3.6$ & 3,520 \\
\hline
\end{tabular}

$11.7 \%, i$-酪酸 4.1\%, $n$-吉草酸 3.0\%, $i$-吉草酸 $9.0 \%$, $i$-カプロン酸 $0.3 \%$ ）であった。供給廃水の $\mathrm{pH}$ は $\mathrm{NaOH}$ を用いて UASB 反応器内の $\mathrm{pH}$ が 6.8-7.5 に維持される ように調整した。

\section{2 運転条件}

表 1 は全運転 656 日間における UASB 反応器の運転条 件を示す。本研究では, UASB 反応器の最大許容 COD 容積負荷（OLR）を調查するために, 供給廃水の COD 濃度の上昇およびHRTの短縮を行い, 3.6-24 kgCOD m ${ }^{-3} \mathrm{~d}^{-1}$ に設定し，運転を行った。模擬奨油製造廃水の調整等に よる人為的誤差のため, 設定 OLR と実際の OLR に差が 見られたため, 以下の OLR は実際の OLRの值を用いた。 発生したバイオガスによるUASB 反応器内保持污泥の流 出を防ぐために運転 620 日目（Phase 6) から原水槽に高 級アルコール系の消泡剂（アンチフロス $\mathrm{M}-8$, ゲンブ） を添加した。消泡剤は原水を作製する際に, 作製原水量 に対し $0.02 \%$ で添加した。

\section{3 分析方法}

水質分析は原水, UASB 処理水, および DHS 処理水 について行った。溶解性試料の分析にはガラス繊維ろ紙 (0.45 $\mu \mathrm{m}$, GB140, ADVANTEC) でろ過した後の試料 を用いた。 $\mathrm{pH}$ は, ポータブル $\mathrm{pH}$ 計 (HM-30P, TOA-DKK) を用い，測定した。全 COD（以下，COD とする）およ 
び溶解性 COD は重クロム酸カリウムによる酸素要求量 （DR4000U，HACH）により測定した。また, COD 濃度 が $150 \mathrm{mgCOD} \mathrm{L}^{-1}$ 以下は LR（HACH メソッド 2710）, 1,500 mgCOD L $\mathrm{m}^{-1}$ 以下は HR（HACH メソッド 2720）を 使用した。SS，VSS，MLSS，およびMLVSS の測定は 下水試験方法に準拠した ${ }^{11)}$ 。溶解性試料に含まれるVFA (酢酸, プロピオン酸, 酪酸, 吉草酸, カプロン酸) は FID 型ガスクロマトグラフ（GC-8A，島津製作所）によ り測定した。測定条件はキャリアガスを高純度窒素 (99.995\%), 充填剂にサーモン 3000 , カラム温度 $125{ }^{\circ} \mathrm{C}$, 注入口および検出器温度 $200{ }^{\circ} \mathrm{C}$ とた。発生バイオガス は脱硫処理を行った後に湿式ガスメーター（W-NK0.5B，シナガワ）で生成ガス量を測定した。バイオガス 中の組成 $\left(\mathrm{CH}_{4}, \mathrm{CO}_{2}, \mathrm{H}_{2}, \mathrm{~N}_{2}\right)$ は TCD 型ガスクロマト グラフ（GC-8A IT，島津製作所）で測定した。測定条 件はキャリアガスを高純度アルゴン $(99.998 \%)$, 充填剂 にユニビース $\mathrm{C}$, カラム温度 $145{ }^{\circ} \mathrm{C}$, 注入口および検出 器温度 $150{ }^{\circ} \mathrm{C}$ とた。

\section{4 16S rRNA 遺伝子解析}

UASB 反応器内保持污泥のサンプリングは port 1 (高 さ $5 \mathrm{~cm}), 3(35 \mathrm{~cm}), 5(65 \mathrm{~cm})$ から運転 248 日目お よび 397 日目に行った。DHS 反応器内保持污泥は運転 397 日目にbox 1 (反応器上部) および box 2 (反応器下 部）から採取した。サンプリングした污泥はニッポンジ ーンの $10 \times \mathrm{PBS}$ を滅菌水で 10 倍希釈したリン酸バッフ アー (1,370 mmol L ${ }^{-1} \mathrm{NaCl}, 81 \mathrm{mmol} \mathrm{L}{ }^{-1} \mathrm{Na}_{2} \mathrm{HPO}_{4}, 26.8$ mmol L ${ }^{-1} \mathrm{KCl}, 14.7 \mathrm{mmol} \mathrm{L}{ }^{-1} \mathrm{KH}_{2} \mathrm{PO}_{4}$ ) で洗浄後, DNA 抽出まで $-20{ }^{\circ} \mathrm{C} て ゙$ 保存した。DNA 抽出には FastDNA Spin Kit for Soil (MP Biomedicals) を使用した。PCR に用いるプライマーセットは原核生物 16S rRNA 遺伝子 を対象とした Univ515F-Univ806R を使用し, PCR 条件 は既報に従った ${ }^{12)}$ 。増幅産物は MinElute PCR Purification Kit（QIAGEN）で精製後, MiSeq（Illumina）を用いて DNA シークエンシングを行った。得られた $16 \mathrm{~S}$ rRNA 遺伝子配列データの解析は Kuroda et al. の方法に従っ た ${ }^{13)}$ 。Operational taxonomic unit (OTU) の分類は 97 \%以上の相同性を持つ DNA シークエンスを同じグルー プとした。16S rRNA 遺伝子配列に基づいた系統樹の作 成はARB program package を用い, Greengenes のデ ータベースを使用した ${ }^{14,15)}$ 。系統樹に用いた長さ 1,000 bp 以上の遺伝子配列は PyNast でアライメントを行った後 に, 近隣結合法を用いて樹形を推定した ${ }^{16)}$ 。系統樹の樹 形の確からしさは 1,000 回の bootstrap 解析により検証し た ${ }^{17)}$ 。本研究で優占していた OTUは PyNast でアライメ ントを行った後にARBの Parsimony Insertion tool を用 いて系統的位置を推定した。優占している OTUはそれ ぞれの反応器で平均約 $2 \%$ 以上存在しているものを選択 した。Weighted UniFrac tree は得られた全てのOTUの 検出率を用い, 樹形の確からしさは QIIME software package を用いて 100 回の Jackknife 解析により検証し た ${ }^{18)}$ 。代表 OTU の $16 \mathrm{~S}$ rRNA 遺伝子配列は DDBJ/ EMBL/GenBank データベースに登録した（LC094360LC094383)。

\section{3. 結果および考察}

\section{1 模擬奨油製造廃水の連続処理実験}

図 2 はUASB-DHS システムにおける模擬奨油製造廃 水の連続処理実験結果を示す。Phase 1-3では, 流入 COD 濃度を上昇もしくは HRT を短縮することで UASB 反応器の OLR を $4.7 \pm 0.9 \mathrm{kgCOD} \mathrm{m}^{-3} \mathrm{~d}^{-1}$ から $9.0 \pm 2.4$ $\mathrm{kgCOD} \mathrm{m} \mathrm{m}^{-3} \mathrm{~d}^{-1}$ まで上昇させた（図 $2 \mathrm{~A}$, 以下，土は標準 偏差を示す)。Phase 1 において, UASB 反応器およびシ ステム全体の COD 除去率は 21-80\%および $24-84 \%$ と大 きく変動し, UASB 反応器ではVFAの突発的な蓄積（運 転 69 日目 : $\left.735 \mathrm{mgCOD} \mathrm{L}{ }^{-1}\right)$ が検出され, その組成の ほとんどは酢酸 $572 \mathrm{mgCOD} \mathrm{L}{ }^{-1}$ ，プロピオン酸 77 $\mathrm{mgCOD} \mathrm{L} \mathrm{L}^{-1}$ であった（図 2B，C）。全システムとしては Phase 2 から 3 にかけて $87 \pm 7 \%$ と, Phase 1 と比較して 高いCOD 除去率を示した（図 2B）。この要因としては, 1) DHS 反応器保持污泥の模擬奨油製造廃水への馴養, 2) UASB 反応器の COD 除去性能の上昇が考えられる。 実際, Phase 1 の UASB 反応器の COD 除去率は $54 \pm 15$ \%であったのに対し, Phase 2-3では $68 \pm 15 \%$ であった。 また, Phase 3 では, 分析不可能な時期が 78 日間（運転 150-227 日目）あったが，運転 228-244 日目（Phase 3 の 後半) において UASB 反応器および全システムの COD 除去率がそれぞれ $82 \pm 3 \%$ および $90 \pm 7 \%$ と, Phase 3 前 半（運転 132-149 日目, UASB : 65 $\pm 19 \%$, 全システム : $84 \pm 6 \%$ ）と比較して高い值を示し，VFA の蓄積も観測 されなかった。UASB 反応器および DHS 反応器内保持 污泥の模擬奨油製造廃水への馴養が十分に行われたと考 え, Phase 4-6（運転 245-656 日目）では流入 COD 濃度

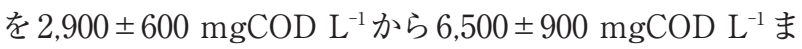
で変化させることで UASB 反応器の OLR $9.0 \pm 2.4$

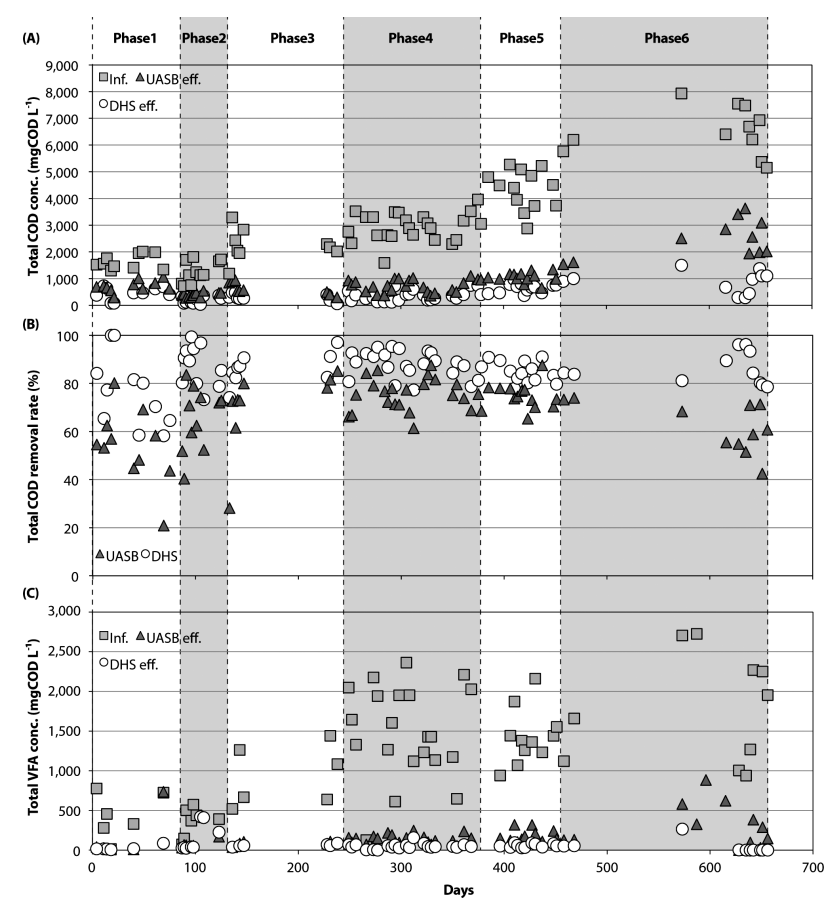

図 2 UASB-DHS システムの連続処理実験結果 (A) COD 濃度, (B) COD 除去率, (C) 全 VFA 濃度 Inf. は流入廃水, eff. は処理水を示す 
$\mathrm{kgCOD} \mathrm{m} \mathrm{m}^{-3} \mathrm{~d}^{-1}$ から $26 \pm 3.6 \mathrm{kgCOD} \mathrm{m}^{-3} \mathrm{~d}^{-1}$ まで上昇さ せた (図 2B)。Phase 5 では, Phase 1-3 と比較して短期 間で OLR $17 \pm 3.2 \mathrm{kgCOD} \mathrm{m}^{-3} \mathrm{~d}^{-1}$ (流入 COD 濃度 : 4,200 $\pm 800 \mathrm{mgCOD} \mathrm{L}^{-1}$ ) まで上昇させたにもかかわらず, COD 除去率は UASB 反応器で $74 \pm 5 \%$, システム全体で $85 \pm 4 \%$ を示した。Phase 6 (OLR : $26 \pm 3.6 \mathrm{kgCOD} \mathrm{m} \mathrm{m}^{-3} \mathrm{~d}^{-1}$ ) では, UASB 反応器内で発泡による保持污泥の槽外への 流出およびVFAの蓄積が発生し, COD 除去率が $62 \pm 10$ \%まで低下したため（図 2B），運転 620 日目から消泡剂 をUASB 反応器に添加し発泡を抑制した。UASB 反応器 の COD 除去率が低下した一方で, Phase 6 におけるシス テム全体の COD 除去率は $87 \pm 7 \%$ を示した。そのため, 本システムは前段の UASB 反応器の COD 除去性能が低 下した場合においても, 後段の DHS 反応器が残存有機 物を処理することで UASB 反応器における OLR $26 \pm 3.6$ $\mathrm{kgCOD} \mathrm{m}{ }^{-3} \mathrm{~d}^{-1}$ (流入 COD 濃度 : 6,500 $\pm 900 \mathrm{mgCOD} \mathrm{L}^{-1}$ ) を許容することが可能であった。また, 全運転期間を通 じてUASB 反応器における発生バイオガス中の平均メ夕 ン濃度は約 $80 \%$ であった。

図 3 は Phase 5 と 6（運転 378-656日目, Phase 5: 17 $\pm 3.2 \mathrm{kgCOD} \mathrm{m}^{-3} \mathrm{~d}^{-1}$, Phase $6: 26 \pm 3.6 \mathrm{kgCOD} \mathrm{m}^{-3} \mathrm{~d}^{-1}$ ) における UASB 反応器の COD 除去速度とメタン生成速 度の関係を示す。COD 除去速度とメタン生成速度は比較

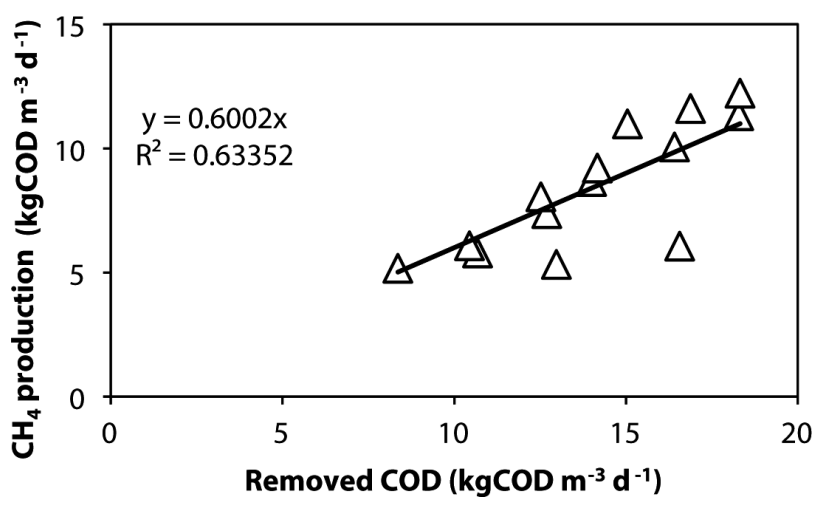

図 3 Phase 5 と 6 における UASB 反応器の COD 除去速度 とメタン生成速度の関係
的強い相関 $\left(\mathrm{R}^{2}=0.63\right)$ を示し, 除去された COD の約 60 \%がメタンに転換されていた。本研究で得られた值は, 低温（17-19 ${ }^{\circ} \mathrm{C}$ ) 条件下で飲料系工場排水を処理する EGSB 反応器を用いた高負荷 $\left(15 \mathrm{kgCOD} \mathrm{m}^{-3} \mathrm{~d}^{-1}\right)$ メ夕 ン発酵処理において得られたメタン転換率（約 64\%）と 近い值を示した ${ }^{10)}$ 。Phase 6 では，VFAのうち，主に酢 酸, プロピオン酸， $i$-酪酸， $n$-酪酸および $i$-吉草酸が UASB 反応器内で蓄積していた。廃水中の高塩濃度は嫌 気性メタン発酵を阻害することや，嫌気性グラニュール 污泥の崩壊を引き起こすことが報告されている ${ }^{19,20)}$ 。本 研究では, OLR $26 \pm 3.6 \mathrm{kgCOD} \mathrm{m}^{-3} \mathrm{~d}^{-1}$ まで有機物負荷 を上昇させるにつれ，塩濃度が増加し， Phase 6 におけ る流入廃水中の塩濃度は約 $3.5 \mathrm{gNa} \mathrm{L}^{-1}$ まで増加した。本 研究で得られた最大 OLR での塩濃度は, 既往の阻害濃 度（塩濃度阻害によってメタン生成量が通常の $50 \%$ まで 低減する濃度, $\mathrm{IC}_{50}$ : 5.6-53 $\left.\mathrm{gNa} \mathrm{L}^{-1}\right)^{19)}$ と比較して低い 值ではあるが, 微生物群集への塩濃度の影響は廃水の組 成, リアクターの運転条件, 他のカチオン類の存在によ って大きく変わってくること乩, Phase 6 において COD 除去率の低下が見られたことから (図 2B), 本研究で用 いたUASB 反応器内保持污泥にも塩濃度が影響を与えた 可能性が考えられた。

3.2 UASB 反応器基軸高さ方向の水質プロファイル

高負荷条件下 (Phase 5: $17 \pm 3.2 \mathrm{kgCOD} \mathrm{m}^{-3} \mathrm{~d}^{-1}$, Phase $\left.6: 26 \pm 3.6 \mathrm{kgCOD} \mathrm{m}^{-3} \mathrm{~d}^{-1}\right)$ における UASB 反応 器の廃水処理過程を調查するために, 運転 437 日目 (Phase 5), 運転 468 日目 (Phase 6 前半) および運転 642 日目 (Phase 6 後半) での UASB 反応器基軸高さ方 向の水質プロファイルを測定した（図 4)。

運転 437 日目（Phase 5）および運転 468 日目（Phase 6 前半) では, 流入した溶解性 COD の $85 \%$ 以上が port 3 (高さ $35 \mathrm{~cm}$ ) までで除去されていた（図 4A)。加え

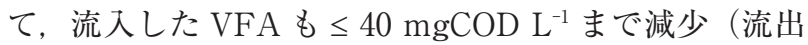
時）し, pH の低下（全高さ方向で約 7.0）も見られなか ったことから, UASB 反応器では溶解性 COD および VFA の除去が行われていた（図 4B，C）。また, Phase 5 および Phase 6 前半期間では, port 1-5 まで 20

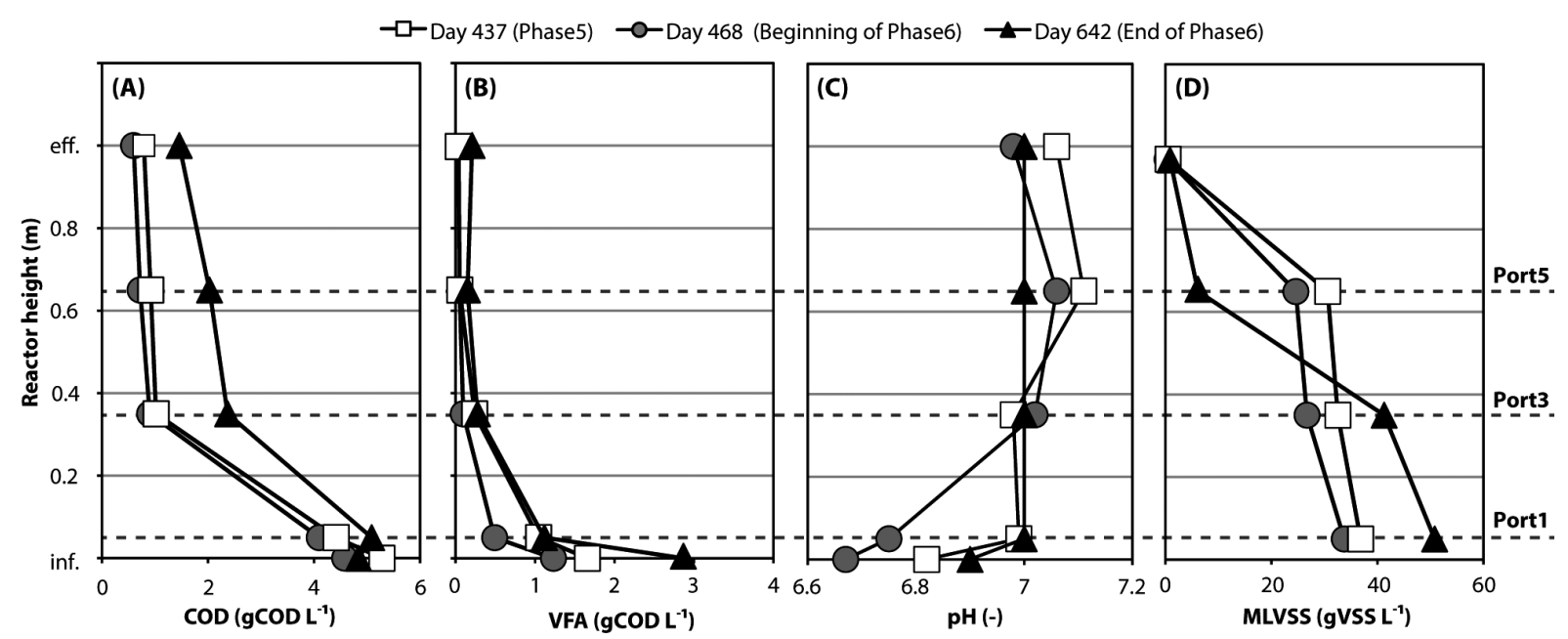

図 $4 \mathrm{UASB}$ 基軸高さ方向における水質プロファイル結果 （A）溶解性 COD 濃度，（B）VFA 濃度，（C） pH，（D） MLVSS 濃度 Inf. は流入廃水, eff. は処理水を示す 
gMLVSS L ${ }^{-1}$ の污泥量を維持していた（図 4D）。

運転 642 日目 (Phase 6 後半) では, Phase 5 および Phase 6 前半と比較して低い有機物除去率を示した（図 $4 \mathrm{~A}$, 流出時 $1,460 \mathrm{mgCOD} \mathrm{L}{ }^{-1}$, 溶解性 COD 除去率約 76 \%)。VFA は, 約 $210 \mathrm{mgCOD} \mathrm{L}^{-1}$ 程度残存しており（流 出時), 特にプロピオン酸が約 $100 \mathrm{mgCOD} \mathrm{L}^{-1}$ 程度残存 していた (図 4B)。これらの原因としてはport $5(65 \mathrm{~cm})$ での保持污泥量の減少が考えられ, 運転 468 日目 (Phase 6 前半) と比較すると約 $30 \mathrm{gMLVSS} \mathrm{L}^{-1}$ から $6 \mathrm{gMLVSS} \mathrm{L}^{-1}$ まで減少していた（図 4D）。これは上述した UASB 反応 器内での発泡により, UASB 反応器内で保持していた污 泥が流出し, 污泥界面が減少することで, 残存 VFAを 分解するための微生物量が保持できなかったためと考え られた。一方で, 消泡剤添加前（運転 587-619日）と添 加後 (運転 620 日以降) の UASB 流出水中の VFA を比 較すると, 消泡剂添加前が 326-884 mgCOD L ${ }^{-1}$ であっ たのに対し, 消泡剂添加後は 0-383 $\mathrm{mgCOD} \mathrm{L}^{-1}$ であっ た（図 2C）。そのため, 実奨油製造廃水処理システムの
実現のためにも, 流入 COD濃度 $6,500 \pm 900 \mathrm{mgCOD} \mathrm{L}^{-1}$, OLR $26 \pm 3.6 \mathrm{kgCOD} \mathrm{m}^{-3} \mathrm{~d}^{-1}$ 程度の高負荷条件下で UASB 反応器を運転する際には, 消泡剤の添加を行うな ど, 発泡による污泥の流出を防ぐ運転管理が重要になる と考えられた。

\section{3 低温 UASB- 常温 DHS システム内保持污泥の微 生物群集構造解析}

\section{3.1 優占して存在する OTUの分子系統解析}

本研究では, $16 \mathrm{~S}$ rRNA 遺伝子に基づき, 低温 UASB常温 DHS システム内保持污泥の微生物叢解析を, 運転 条件が異なる 248 日目 (Phase 4, $12 \pm 2.2 \mathrm{kgCOD} \mathrm{m}^{-3} \mathrm{~d}^{-1}$ ) と 397 日目 (Phase $5,17 \pm 3.2 \mathrm{kgCOD} \mathrm{m}^{-3} \mathrm{~d}^{-1}$ ) に行な うことで, OLR 増加に伴う微生物群集構造変化を評価し た。Phase 4 およびPhase 5 において, Euryarchaeota 門, Deltaproteobacteria 綱, Firmicutes 門, Synergistetes 門，Bacteroidetes 門に属する OTU が優占して検出され た (図 5)。Jackknife-supported weighted UniFrac 解析 の結果, 運転 248 日目では UASB 反応器の port $1,3,5$

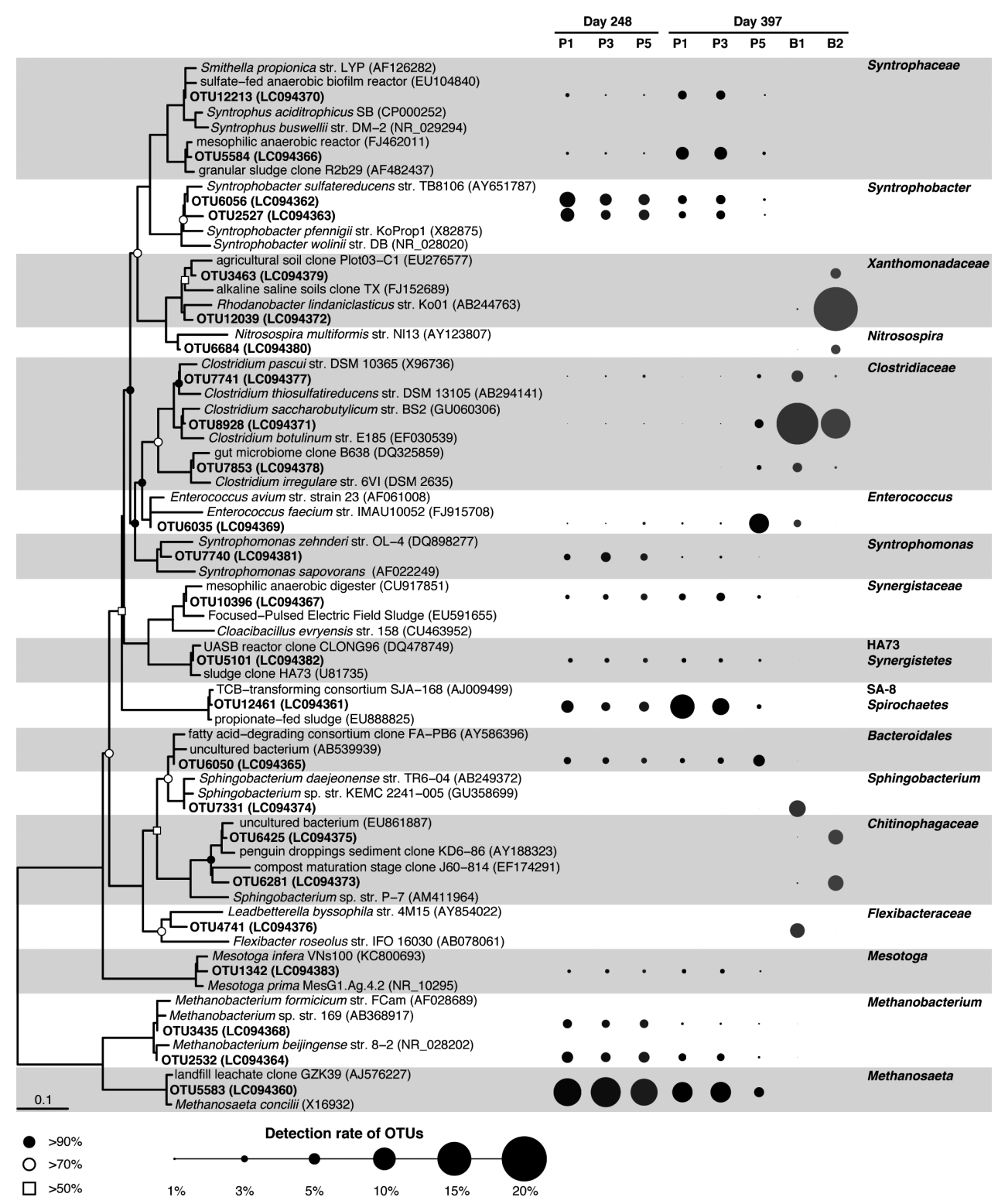

図 5 UASB 反応器及び DHS 反応器内保持污泥中の微生物叢解析結果

P1，P3，P5 は UASB 反応器の Port 1，3，5 を示す。B1 及び B2 は DHS 反応器の box 1, 2 を示す。 
において優占して存在している微生物群に殆ど変化が無 い一方で, 運転 397 日目では port 5 のみが異なる微生物 叢を示しており，全ての nodeで 95\%以上支持されてい た (図 6)。DHS 反応器では Clostridiaceae 科に属する微 生物群を除いて, 上部 (box 1) と下部（box 2) で異な る微生物群が優占して存在していた（図 5, 図 6)。

UASB 反応器内保持污泥中の細菌では, Syntrophaceae 科, Syntrophobacter 属, Syntrophomonas 属に属する栄 養共生菌が優占して検出（平均 $2 \%$ 以上）された（図 5)。 これら微生物群は, 水素資化性の微生物群と共生関係を 担うことでVFAなどを分解することが知られており ${ }^{22,23)}$, 廃水中の約 $40 \%$ を占める VFA, および, 模擬奨油製造 廃水分解過程において生成されるVFAの除去に関与し ていると考えられた。加えて, 嫌気性廃水処理污泥中で 普遍的に存在する SA-8 (Spirochaetes 門) やBacteroidales 目に属する未培養微生物群も存在割合 $2 \%$ 以上と優占し て検出された。これらのグループに属する分離株はアミ ノ酸分解や, タンパク質などの高分子化合物を加水分解 することが知られている。加えて, メタゲノムおよびメ タトランスクリプトム解析により, SA-8に属する“Ca. Argininisyntropha thermophila” はアルギニンを分解す る栄養共生細菌であることが示唆されている ${ }^{25)}$ 。奨油は アミノ酸を豊富に含んでおり, これら微生物群が模擬奨 油製造廃水中のタンパク質やアミノ酸分解を担っている 可能性が示唆された。

DHS 反応器において, 反応器上部 (box 1) では, デ ンプンなどの高分子化合物の加水分解や糖などを利用す るSphingobacterium 属 ${ }^{25)}$ や Leadbetterella 属 ${ }^{26)}$ に近縁な OTU7331 と OTU4741 が box 1 特異的に存在していた (図 5)。一方, 反応器下部（box 2) では, アンモニア酸 化細菌として知られているNitrosospira 属 ${ }^{27)}$ (OTU6684)，酢酸などを電子供与体として脱窒を行なう 細菌を含む Rhodanobacter 属 ${ }^{28)}$ に近縁な OTU3463 と OTU12039 が box 2 特異的に検出された。本研究では,

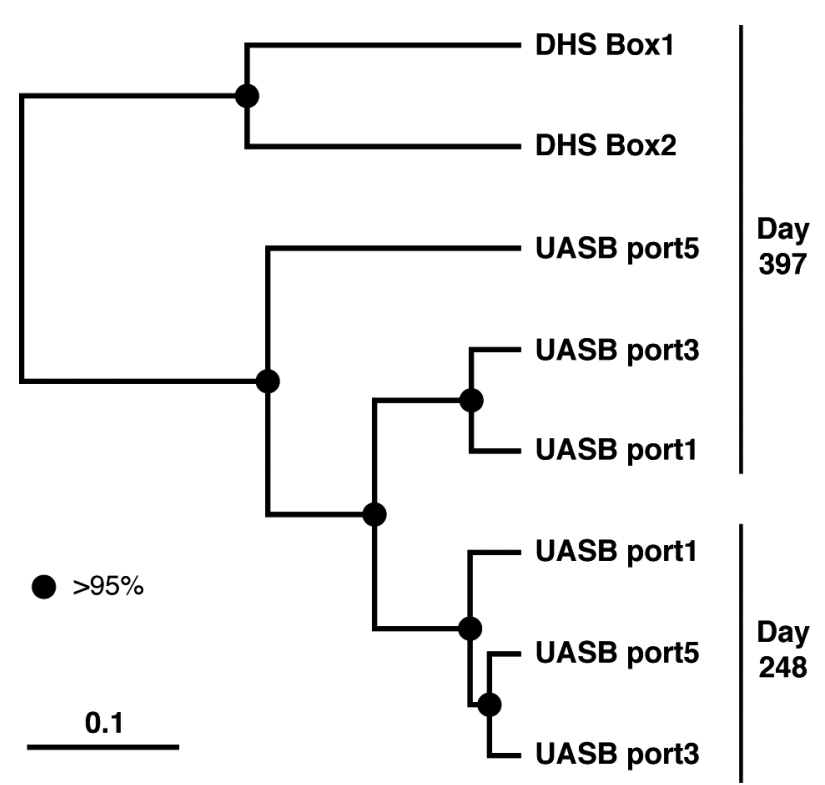

図 6 運転 248 日目（Phase 4）及び 397 日目（Phase 5）に おける各污泥サンプル中の OTU 検出率に基づいた Jackknife-supported weighted UniFrac tree
有機物除去を目的としたために窒素濃度を測定していな いが, 微生物叢解析の結果から, DHS 反応器上部では Sphingobacterium 属, Leadbetterella 属や Clostridiaceae 科による高分子化合物の加水分解などによる有機物分解 が, DHS 反応器下部では Clostridiaceae 科による残存有 機物の分解や Nitrosospira 属および Rhodanobacter 属に よる窒素除去が行われている可能性が考えられた。DHS 反応器では, スポンジの表面に好気性細菌や硝化細菌が 増殖し，その内側には嫌気性細菌もしくは脱窒細菌が保 持されることが報告されており ${ }^{29)}$, DHS 反応器下部にお けるアンモニア酸化細菌および脱窒細菌の検出結果は, これまでの報告と同様に, DHS 反応器内で窒素除去が起 こっていることを示唆するものであった。

\section{3.2 UASB 反応器内保持污泥中の VFA 分解微生物群}

本研究で用いた模擬奨油製造廃水の COD の約 $40 \%$ は VFA で構成されているため, UASB 反応器中の有機物 分解のためにはVFA 分解微生物群の存在が重要である。 図7は運転397日目 (Phase 5, OLR 17 $\pm 3.2 \mathrm{kgCOD} \mathrm{m}^{-3} \mathrm{~d}^{-1}$ ) における UASB 反応器の基軸高さ方向 VFA プロファイ ルとVFA 分解微生物群の検出パターンを示す。Phase 5 において, $561 \mathrm{mgCOD} \mathrm{L} \mathrm{L}^{-1}$ で流入した酢酸は port 1 で 速やかに $105 \mathrm{mgCOD} \mathrm{L}^{-1}$ まで分解され, port 3 以降で は, $41 \mathrm{mgCOD} \mathrm{L} \mathrm{L}^{-1}$ まで低下した（図 7A）。酢酸資化性 メタン生成古細菌として知られる Methanosaeta 属に属す る OTU5583 は酢酸分解が生じた port 1 と 3 で約 $9.0 \%$ 存 在しており, その後, port 5 では 4.4\%まで低下した。加 えて, 近年のオミクスアプローチにより, 水素資化性微 生物と栄養共生関係を持ち酢酸酸化を行うことが推定さ れたMesotoga 属 ${ }^{24)}$ の OTU1342, microautoradiographyfluorescence in situ hybridization 法と RNA-stable isotope probing 法を組み合わせたアプローチにより酢酸利用性 微生物として推定された系統分類に近縁な OTU5101 (HA73, Synergistetes 門) ${ }^{30)}$ も OTU5583 (Methanosaeta) と同様の検出パターンを示した（図 7A）。この挙動は UASB 反応器内の酢酸の消費と一致しており, これら微 生物群が廃水中の酢酸を分解していると考えられた。プ ロピオン酸においても約 $400 \mathrm{mgCOD} \mathrm{L}{ }^{-1}$ で流入し, port 1 で約 $170 \mathrm{mgCOD} \mathrm{L}^{-1}$, port 3 で $30 \mathrm{mgCOD} \mathrm{L}^{-1}$ まで減 少した（図 7B）。プロピオン酸を分解する栄養共生細菌 であるSyntrophobacter属, Smithella 属に属する OTU6056, OTU2527, OTU12213 は port 1, 3 で約 3-4\%程度存在 し, プロピオン酸が殆ど消費された port 5 では約 $1 \%$ の 存在割合まで低下した。プロピオン酸分解反応の進行の ためには, 他のVFA と比較して極めて低い水素分圧が 重要であることが報告されており ${ }^{23)}$, Phase 5 における UASB 反応器内のプロピオン酸の挙動およびプロピオン 酸分解微生物群の検出パターンから, OLR $17 \pm 3.2$ $\mathrm{kgCOD} \mathrm{m} \mathrm{m}^{-3} \mathrm{~d}^{-1}$ の高負荷条件下においても低水素分圧を 維持出来ていたことが示唆された。酪酸および吉草酸で は, $i$-酪酸と $n$-吉草酸の濃度は流入から port 1 にかけて それぞれ 32 から $90 \mathrm{mgCOD} \mathrm{L}^{-1}, 12$ から $21 \mathrm{mgCOD} \mathrm{L}^{-1}$ と増加したが, port 5 までで完全に消費された。 $n^{\text {-酪酸 }}$ (流入 $\left.147 \mathrm{mgCOD} \mathrm{L}^{-1}\right)$ と $i$-吉草酸 $\left(87 \mathrm{mgCOD} \mathrm{L}^{-1}\right)$ も 同様に port 5 までで検出限界レベルまで減少した（図 7C)。そのため, phase 5 では, 吉草酸および酪酸の蓄積 は見られず, VFA 分解微生物群によって速やかに消費さ 


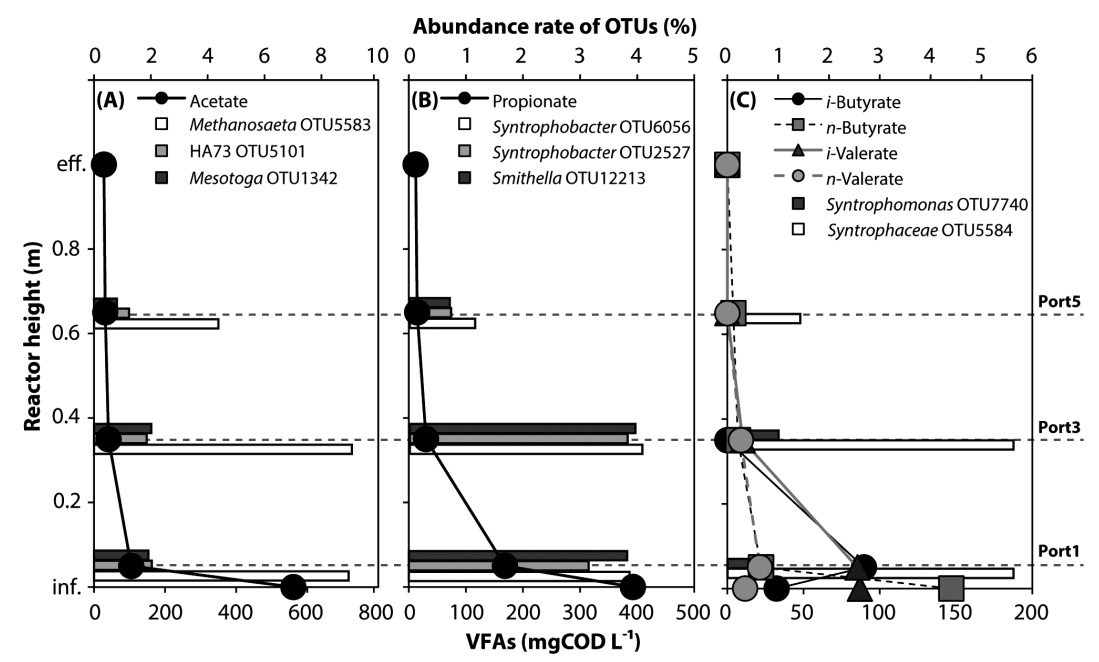

図 7 Phase 5 における UASB 反応器の基軸高さ方向のVFA プロファイルとVFA 分解微生物群の検出パターン （A）酢酸分解微生物，（B）プロピオン酸酸化細菌，（C）酪酸及び吉草酸分解細菌

れていると考えられた。しかしながら，吉草酸もしくは 酪酸分解可能なSyntrophomonas 属 ${ }^{22)}$ に属する OTU7740 は port 1 および $3 て ゙$ 約 $1 \%$ 程度しか検出されなかった（図 5, 図 7C)。一方で, OTU5584 が port 1 から 3 にかけて $5.6 \%$ と優占して検出された。この OTUはS. propionica strain LYP (NR_024989) に 93\% (233/251 bp), S. aciditrophicus strain SB (NR_102776) に92\% (230/251 bp）と比較的近縁であるため, これら微生物と同様にプ ロピオン酸, 酪酸もしくは安息香酸分解性栄養共生細菌

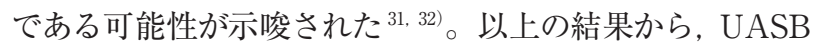
反応器内に扔ける模擬㽜油製造廃水中の VFA は, 酶酸: メ夕ン生成古細菌㧍よび Synergistetes 門と Mesotoga 属 に属する酢酸酸化細菌, プロピオン酸： Deltaproteobacteria 綱に属する栄養共生細菌と水素資化 性メタン生成古細菌, 酪酸扔よび吉草酸: Deltaproteobacteria 綱掞よび Firmicutes 門に属する栄養 共生細菌と水素資化性メタン生成古細菌により分解され ていることが示唆された。

\section{4. まとめ}

本研究では, 実滰油製造廃水に適用可能な処理システ ムの開発を目的として, 低温 UASB- 常温 DHS システム による模擬酱油製造廃水の連続処理実験および保持污泥 の微生物叢解析を行った。本研究で得られた主な結論を 以下に示す。

1) UASB-DHS システムは, 塩濃度約 $3.5 \mathrm{gNa} \mathrm{L}^{-1}$, 流 入 $\mathrm{COD}$ 濃度 $6,500 \pm 900 \mathrm{mgCOD} \mathrm{L}^{-1}$ および UASB 反応器の OLR : $26 \pm 3.6 \mathrm{kgCOD} \mathrm{m}^{-3} \mathrm{~d}^{-1}$ の条件下で $87 \pm 7 \%$ の COD 除去率を達成し, UASB 反応器の 有機物除去能力が低下した場合においてもシステム としては有機物除去能力を維持していた。

2) UASB 反応器の単独処理では, 消泡剂を添加せず に有機物を除去可能な最大許容 OLR は, OLR：17 $\pm 3.2 \mathrm{kgCOD} \mathrm{m}^{-3} \mathrm{~d}^{-1}$ であり, UASB 反応器の COD 除去率は $74 \pm 5 \%$ を示した。

3）UASB 基軸高さ方向の水質プロファイルの結果, 高 負荷 (OLR：26 $23.6 \mathrm{kgCOD} \mathrm{m}^{-3} \mathrm{~d}^{-1}$ ) 条件下で UASB 反応器の運転を行う際には, 消泡剂の添加
を行うなど, UASB 反応器保持污泥の流出を防ぐ ための運転管理が重要であることが示唆された。

4) Phase 5 (OLR $17 \pm 3.2 \mathrm{kgCOD} \mathrm{m}^{-3} \mathrm{~d}^{-1}$ ) における UASB 反応器の基軸高さ方向の VFA プロファイル とVFA 分解微生物群の検出パターンを評価した結 果, 酢酸, プロピオン酸, 酪酸㧍よび吉草酸は Deltaproteobacteria 綱, Firmicutes 門, Thermotogae 門に属する栄養共生細菌, Synergistetes 門細菌およびメタン生成古細菌によっ て分解されていることが示唆され，低温・高有機物 負荷運転条件下においても, UASB 反応器内では 栄養共生関係を維持できていると考えられた。

\section{謝 辞}

本研究実施にあたりメンテナンスや分析作業に尽力し て頂いた鹿児島工業高等専門学校の有村圭右氏（現：日 特建設株式会社), 溝口直人氏 (現：通信土木コンサルタ ント株式会社）に深く感謝の意を表します。また, 本研 究の一部はJST マッチングプランナー（課題番号： MP27115663589）から助成を受け実施されました。ここ に記して感謝の意を表します。

（原稿受付 2016 年 2 月 22 日） （原稿受理 2016 年 11 月 17 日）

\section{参 考 文 献}

1）しょうゆ情報センター, 2015. 醤油の統計資料平成 27 年版. URL. https://www.soysauce.or.jp/arekore/ (2016 年 2 月時点). 2 ）一般財団法人食品産業センター. 槒油製造工場 HACCP 手法導 入マニュアル（奨油工場の一般衛生管理事項）.URL. https:// www.shokusan.or.jp/haccp/guide/pdf/3_2_5_syouyu_2.pdf (2016 年 2 月時点).

3 ) Kleerebezem, R., Macarie, H., 2003. Treating industrial wastewater: Anaerobic digestion comes of age. Chemical Engineering 110(4), 56-64.

4 ) Kuroda, K., Chosei, T., Nakahara, N., Hatamoto, M., Wakabayashi, T., Kawai, T., Araki, N., Syutsubo, K., Yamaguchi, T., 2015. High organic loading treatment for industrial molasses wastewater and microbial community shifts corresponding to system development. Bioresource Technology 196, 225-234.

5 ) Lettinga, G., Rebac, S., Zeeman, G., 2001. Challenge of psychrophilic anaerobic wastewater treatment. Trends in 
Biotechnology 19(9), 363-370.

6 ) Veeresh, G.S., Kumar, P., Mehrotra, I., 2005. Treatment of phenol and cresols in upflow anaerobic sludge blanket (UASB) process: a review. Water Research 39(1), 154-170.

7 ) Yamada, M., Harada, H., Yamauchi, M., Yamaguchi, T., Ohashi, A., 2013. Reduction of alkali supplement in a pilot-scale thermophilic multi-staged UASB reactor treating alcohol distillery wastewater. International Journal of Environmental Research 7(4), 823-830.

8 ) Kubota, K., Hayashi, M., Matsunaga, K., Iguchi, A., Ohashi, A., Li, Y.Y., Yamaguchi, T., Harada, H., 2014. Microbial community composition of a down-flow hanging sponge (DHS) reactor combined with an up-flow anaerobic sludge blanket (UASB) reactor for the treatment of municipal sewage. Bioresource Technology 151, 144-150.

9 ) 有田明人, 松本源生, 石橋融子, 馬場義輝, 2013. 福岡県の地 下水温について. 福岡県保健環境研究所年報 40, 133-134.

10）藤本典之, 稲葉英樹, 窪田恵一, 珠坪一晃, 2013. EGSB 法に よる飲料系工場排水の無加温メ夕ン発酵処理技術の開発. 土木学 会論文集 G（環境）69(7)，623-630.

11）建設省都市局下水道部，厚生省生活衛生局水道環境部監修, 1997. 下水試験方法 (上巻)。 日本下水道協会, 東京.

12) Caporaso, J.G., Lauber, C.L., Walters, W.A., Berg-Lyons, D., Huntley, J., Fierer, N., Owens, S. M., Betley, J., Fraser, L., Bauer, M., Gormley, N., Gilbert, J.A., Smith, G., Knight, R., 2012. Ultra-high-throughput microbial community analysis on the Illumina HiSeq and MiSeq platforms. ISME Journal 6(8), $1621-1624$

13) Kuroda, K., Hatamoto, M., Nakahara, N., Abe, K., Takahashi, M., Araki, N., Yamaguchi, T., 2015. Community composition of known and uncultured archaeal lineages in anaerobic or anoxic wastewater treatment sludge. Microbial Ecology 69(3), 586-596.

14) Ludwig, W., Strunk, O., Westram, R., Richter, L., Meier, H., Yadhukumar, Buchner, A., Lai, T., Steppi, S., Jobb, G., Forster, W., Brettske, I., Gerber, S., Ginhart, A.W., Gross, O., Grumann, S., Hermann, S., Jost, R., Konig, A., Liss, T., Lussmann, R., May, M., Nonhoff, B., Reichel, B., Strehlow, R., Stamatakis, A., Stuckmann, N., Vilbig, A., Lenke, M., Ludwig, T., Bode, A., Schleifer, K.H., 2004. ARB: a software environment for sequence data. Nucleic Acids Research 32(4), 1363-1371.

15) McDonald, D., Price, M.N., Goodrich, J., Nawrocki, E.P., DeSantis, T.Z., Probst, A., Andersen, G.L., Knight, R., Hugenholtz, P., 2012. An improved Greengenes taxonomy with explicit ranks for ecological and evolutionary analyses of Bacteria and Archaea. ISME Journal 6(3), 610-618.

16) Caporaso, J.G., Bittinger, K., Bushman, F.D., DeSantis, T.Z., Andersen, G.L., Knight, R.J., 2010. PyNAST: a flexible tool for aligning sequences to a template alignment. Bioinformatics 26 (2), 266-267.

17) Felsenstein, J., 1985. Confidence-limits on phylogenies - an approach using the bootstrap. Evolution 39(4), 783-791.

18) Caporaso, J.G., Kuczynski, J., Stombaugh, J., Bittinger, K., Bushman, F.D., Costello, E.K., Fierer, N., Pena, A.G., Goodrich, J.K., Gordon, J.I., Huttley, G.A., Kelley, S.T., Knights, D., Koenig, J.E., Ley, R.E., Lozupone, C.A., McDonald, D., Muegge, B.D., Pirrung, M., Reeder, J., Sevinsky, J.R., Turnbaugh, P.J., Walters, W.A., Widmann, J., Yatsunenko, T., Zaneveld, J., Knight, R., 2010. QIIME allows analysis of high-throughput community sequencing data. Nature Methods 7(5), 335-336.
19) Chen, Y., Cheng, J.J., Creamer, K.S., 2008. Inhibition of anaerobic digestion process: a review. Bioresource Technology 99 (10), 4044-4064.

20) Vallero, M.V.G., Pol, L.W.H., Lettinga, G., Lens, P.N.L., 2003. Effect of $\mathrm{NaCl}$ on thermophilic (55 degrees C) methanol degradation in sulfate reducing granular sludge reactors. Water Research 37 (10), 2269-2280.

21) Kugelman, I.J., Chin, K.K., 1971. Toxicity, synergism, and antagonism in Anaerobic waste treatment processes. Advances in Chemistry Series 105, 55-90.

22) Worm, P., Koehorst, J.J., Visser, M., Sedano-Nunez, V.T., Schaap, P.J., Plugge, C.M., Sousa, D.Z., Stams, A.J., 2014. A genomic view on syntrophic versus non-syntrophic lifestyle in anaerobic fatty acid degrading communities. Biochimica et Biophysica Acta (BBA) 1837 (12), 2004-2016.

23) Schink, B., Stams, A.J.M., 2006. Syntrophism among prokaryotes. Springer, New York, U.S.A.

24) Nobu, M.K., Narihiro, T., Rinke, C., Kamagata, Y., Tringe, S.G., Woyke, T., Liu, W.T., 2015. Microbial dark matter ecogenomics reveals complex synergistic networks in a methanogenic bioreactor. ISME Journal 9(8), 1710-1722.

25) Kim, K.H., Ten, L.N., Liu, Q.M., Im, W.T., Lee, S.T., 2006. Sphingobacterium daejeonense sp. nov., isolated from a compost sample. International Journal of Systematic and Evolutionary Microbiology 56 (9), 2031-2036.

26) Weon, H.Y., Kim, B.Y., Kwon, S.W., Park, I.C., Cha, I.B., Tindall, B.J., Stackebrandt, E., Trüper, H.G., Go, S.J., 2005. Leadbetterella byssophila gen. nov., sp. nov., isolated from cotton-waste composts for the cultivation of oyster mushroom. International Journal of Systematic and Evolutionary Microbiology 55(6), 2297-2302.

27) Norton, J.M., Klotz, M.G., Stein, L.Y., Arp, D.J., Bottomley, P.J., Chain, P.S., Hauser, L.J., Land, M.L., Larimer, F.W., Shin, M.W., Starkenburg, S.R., 2008. Complete genome sequence of Nitrosospira multiformis, an ammonia-oxidizing bacterium from the soil environment. Applied and Environmental Microbiology 74(11), 3559-3572.

28) Nalin, R., Simonet, P., Vogel, T.M., Normand, P., 1999. Rhodanobacter lindaniclasticus gen. nov., sp. nov., a lindanedegrading bacterium. International Journal of Systematic Bacteriology 49(1), 19-23.

29) Onodera, T., Tandukar, M., Sugiyana, D., Uemura, S., Ohashi, A., Harada, H., 2014. Development of a sixth-generation downflow hanging sponge (DHS) reactor using rigid sponge media for post-treatment of UASB treating municipal sewage. Bioresource Technology 152, 93-100.

30) Ito, T., Yoshiguchi, K., Ariesyady, H.D., Okabe, S., 2011. Identification of a novel acetate-utilizing bacterium belonging to Synergistes group 4 in anaerobic digester sludge. ISME Journal 5(12), 1844-1856.

31) Liu, Y., Balkwill, D.L., Aldrich, H.C., Drake, G.R., Boone, D.R., 1999. Characterization of the anaerobic propionate-degrading syntrophs Smithella propionica gen. nov., sp. nov. and Syntrophobacter wolinii. International Journal of Systematic Bacteriology 49(1), 19-23.

32) Jackson, B.E., Bhupathiraju, V.K., Tanner, R.S., Woese, C.R., McInerney, M., 1999. Syntrophus aciditrophicus sp. nov., a new anaerobic bacterium that degrades fatty acids and benzoate in syntrophic association with hydrogen-using microorganisms. Archives of Microbiology 171(2), 107-114. 


\section{[論 文 要 旨]}

本研究では, 配油製造廃水に適用可能な処理システムの構築を最終目的として, 地下水の加温利用を考慮 した創エネルギー型である低温UASB 反応器と省エネルギー型好気性処理である無加温 DHS 反応器を組み わせたシステムにより模擬酱油製造廃水の連続処理実験を行った。その結果，UASB-DHS システムは，塩 濃度約 $3.5 \mathrm{gNa} \mathrm{L}^{-1}$, 流入 COD 濃度 $6,500 \pm 900 \mathrm{mgCOD} \mathrm{L}^{-1}$ および UASB 反応器における有機物負荷 $26 \pm 3.6$ $\mathrm{kgCOD} \mathrm{m} \mathrm{m}^{-3} \mathrm{~d}^{-1}$ の条件下で $87 \pm 7 \%$ の COD 除去率を達成した。また，16S rRNA 遺伝子解析に基づいた微生 物叢解析の結果, 廃水中の COD の約 $40 \%$ を占める揮発性有機酸はDeltaproteobacteria 綱, Firmicutes 門, Thermotogae 門に属する栄養共生細菌, Synergistetes 門細菌とメタン生成古細菌により分解されていること を推定した。

キーワード：模擬奨油製造廃水；生物学的廃水処理；UASB-DHS システム；微生物群集構造解析 
